\title{
Schwartz's Human Values and the Care for Nature in Croatia and Five Other Central European Countries Based on ESS Data from Round 4 (2008) and Round 9 (2018)
}

DOI: $10.5613 /$ rzs.51.3.5

UDC 502.12(497.5+4-191.9)

Original Research Article

Received: 21 February 2021

Bruno ŠIMAC (D) https://orcid.org/0000-0003-1361-9622

Department of Sociology, Faculty of Humanities and Social Sciences, University of Zagreb, Croatia

bsimac@ffzg.hr

Tijana TRAKO POLJAK (D) htps://orcid.org/0000-0002-0846-2889

Department of Sociology, Faculty of Humanities and Social Sciences, University of Zagreb, Croatia

ttrako@ffzg.hr

Vladimir IVANOVIĆ (D) https://orcid.org/0000-0001-8789-3486

Department of Sociology, Faculty of Humanities and Social Sciences, University of

Zagreb, Croatia

vivanovi@ffzg.hr

\section{ABSTRACT}

This paper examines the care for nature in Croatia based on the European Social Survey (ESS) data from Round 4 (2008) and Round 9 (2018) over time and crossnationally, in comparison with five other Central European (CE) countries (Czech Republic, Hungary, Poland, Slovakia and Slovenia). We correlate the item about the care for nature with Schwartz's Human Values Scale (HVS), as adapted for the ESS, to investigate whether values as defined by Schwartz serve as good predictors of the care for nature in selected CE countries. We also look at the correlation with respondents' socio-demographic characteristics. Our analysis reveals that, while there are similarities regarding environmental attitudes and values among CE countries, there are also some individual differences. Croatia shows the strongest increase in the support for the care for nature over the 10-year period, and both Croatia and Slovenia score the highest on the care for nature in 2018. Poland, Slovakia and Czech Republic show an overall stagnation in the results, while Hungary exhibits a significant decrease between 2008 and 2018. Our research in CE countries confirms that Schwartz's HVS can be predictive of pro-environmentalism. However, while the findings for the higher-order value of Selftranscendence are in line with existing literature, the result suggesting that Conservatism is also a moderately good predictor of the care for nature is somewhat surprising. We 
posit that the reason could lie in the difference between collectivist vs. individualist value types, which provides a new dimension for the interpretation of environmental attitudes in these countries.

Key words: Human Values Scale, pro-environmental attitudes, European Social Survey, Croatia, Central Europe

\section{INTRODUCTION}

In the context of the ongoing global social-ecological crisis, investigating pro-environmental attitudes and behaviour has become imperative to detect areas that can be improved to ensure better environmental protection. Even though pro-environmental attitudes do not automatically translate to pro-environmental behaviour, it is important to understand whether and to what extent the potential for such behaviour exists among individuals and societies. Furthermore, it is necessary to identify the factors that influence environmental attitudes so that they can also be targeted through more specific and, thus, more effective education, information, and policies.

In this paper, we analyse the European Social Survey (ESS) data from Round 4 (2008) and Round 9 (2018) to determine what they reveal about environmental attitudes, conceptualised as the care for nature in the ESS. We look at the data cross-nationally, by comparing Croatia and five other Central European (CE) countries (Czech Republic, Hungary, Poland, Slovakia and Slovenia), and over time, during this 10-year period. Besides their common geopolitical position, selected CE countries share socio-cultural characteristics, based on their similar experience of political, economic and social transition from communism/socialism to liberal democracy, as well as the integration into the European Union (EU). We, therefore, want to investigate whether they also exhibit similar environmental attitudes regarding the item about the care for nature, or whether there are differences between individual CE countries, as well as between the former Warsaw pact (Czech Republic, Poland, Slovakia, and Hungary) (FW) and former Yugoslavian countries (Croatia and Slovenia) (FY).

The ESS relies on adapted Schwartz's Human Values Scale (HVS) in measuring values across nations, so we also want to examine whether it served as a good predictor of the care for nature in selected CE countries. It is valuable to examine the predictive strength of Schwartz's values model for pro-environmentalism in Croatia and CE countries as it can provide a new dimension for the interpretation of their environmental attitudes and trends, as well as add to the discussion in the wider literature on the relationship between Schwartz's HVS and pro-environ- 
mentalism. In addition, we correlate the item about the care for nature with respondents' key socio-demographics (age, gender, education, political orientation, and religiosity) to see whether these internal factors are as good predictors in our research as reported across other studies.

\section{THEORETICAL BACKGROUND}

\subsection{Environmental attitudes}

Environmental attitudes have been measured by different conceptual tools to reflect the fact that they cannot be univocally defined. Most widely used are measures focusing on anthropocentric-eco/biocentric orientations (e.g., the New Environmental Scale, or NEP, by Dunlap and Van Liere, 1978; Dunlap et al., 2000), environmental awareness and willingness to act (e.g., the Ecology Scale by Maloney and Ward, 1973), and environmental concern and consciousness (e.g., the Environmental Concern Scale by Weigel and Weigel, 1978). Later studies have also looked at the ethical motivation for human behaviour toward the natural environment by including the affective component (i.e., feelings of connectedness, belonging, empathy, respect, and care; Schultz, 2001; Schultz et al., 2004; Mayer and Frantz, 2004; Müller, Kals and Pansa, 2009; Kals, Schumacher and Montada, 1999; Stern, 2000), as well as ethical orientations, such as utilitarianism (e.g., the Environmental Perception Scale by Wiseman and Bogner, 2003) or deontology (i.e., the sense of duty and responsibility; e.g., the Environmental Attitudes Scale by Kaiser et al., 1999; Frick, Kaiser and Wilson, 2004).

We analyse environmental attitudes conceptualised as the "care for nature" in the ESS by relying on the item "He/She strongly believes that people should care for nature. Looking after the environment is important to him/her." from ESS Round 4 (2008) and Round 9 (2018). Throughout the paper we use the abbreviated survey item "care for nature" and it should be kept in mind that this item relates more to an injunction to humans to care for nature rather than active care ("should care", "environment is important").

\subsection{Schwartz's model of human values}

As for the predictors of pro-environmental attitudes, Dunlap (2018: xxi-xxiii) gives a good overview of socio-psychological predictors of pro-environmentalism such as the Value-Belief-Norm theory (Stern, 2000), where beliefs are often measured using the NEP Scale (Dunlap et al., 2000), rational choice theory and theory of planned behaviour (Diekmann and Schmidt, 1998; Oreg and Katz-Gerro, 2006), globalisa- 
tion theory (Brechin and Kempton, 1994), and affluence/postmaterialism theory (Inglehart, 1981; Abramson and Inglehart, 1995). Most prominently used measures of values in large social surveys are Inglehart's (1990; Abramson and Inglehart, 1995) materialism/postmaterialism index in the World Values Survey (WVS), European Values Survey (EVS) and International Social Survey Programme (ISSP), and Schwartz's (1992; 1994) HVS, in the ESS, which we rely on in this paper.

Schwartz's HVS conceptualizsd 10 basic motivational values situated along four key dimensions of higher-order values: Self-transcendence vs. Self-enhancement, and Conservatism vs. Openness to change (Figure 1). Schwartz argued that these values can explain most core values found in all world societies. In the adapted HVS for the ESS, 10 basic human values are measured by 21 items, as two-item indexes, except Universalism, which is a three-item index (the original full scale consists of 57 items) (Schwartz, 2003: 284-286).

Figure 1. Schwartz's model of human values (source: Schwartz, 2003: 270, reproduced with permission)

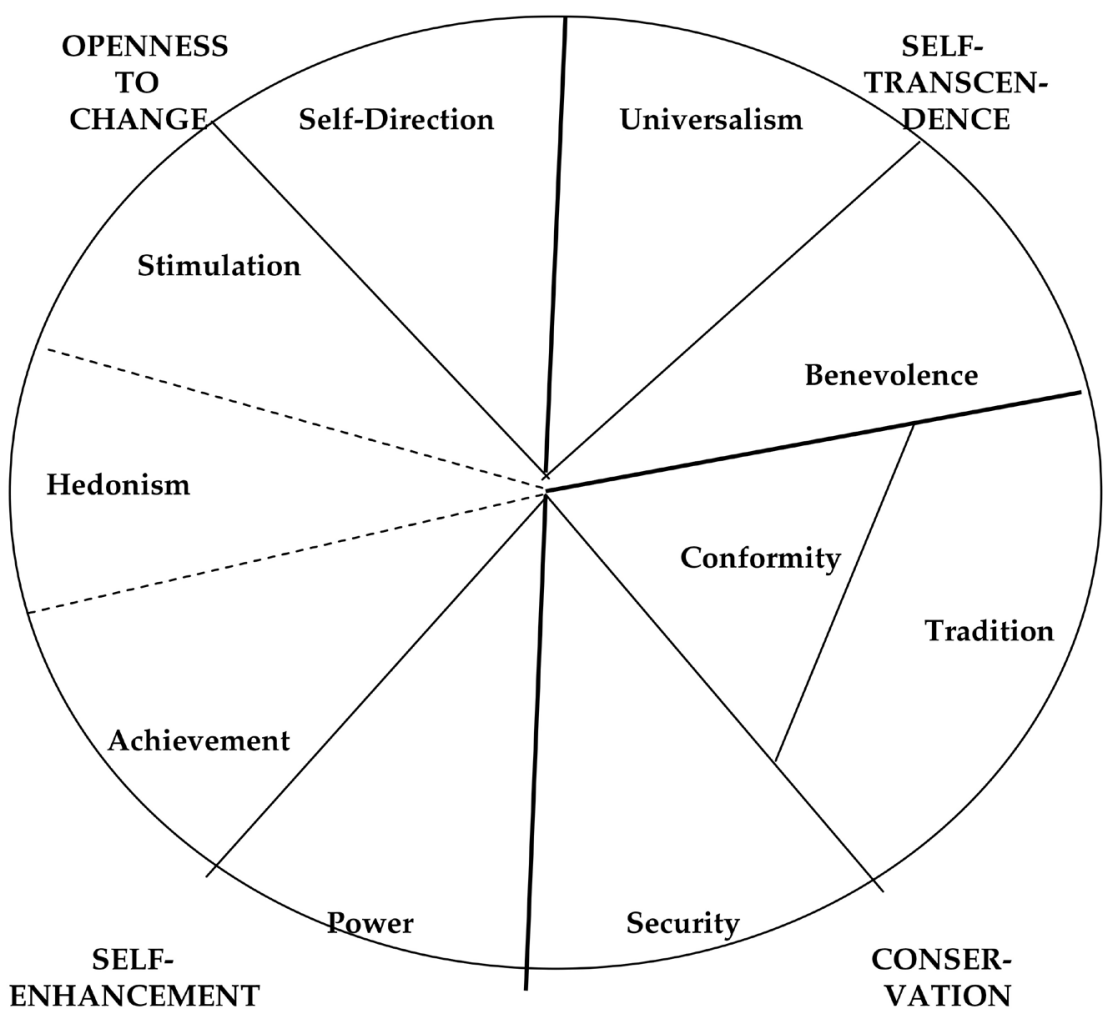


Studies on pro-environmental attitudes and HVS have revealed that among the higher-order values, Self-transcendence correlates with pro-environmental concerns the most, while Self-enhancement correlates the least (Schultz and Zelezny 1999; Stern, 1999). The findings for the higher-order values of Conservatism and Openness to change are less clear but suggest a negative relationship between the measures of general environmental concern and Conservatism (Schultz and Zelezny, 2003). Furthermore, for basic values, in their 14-country analysis, Schultz and Zelezny (1999) found that Universalism (within the higher-order value of Self-transcendence) correlates with pro-environmental attitudes (ecocentrism) positively, while Power (within Self-enhancement) and Tradition (within Conservatism) correlate negatively, as measured by the NEP Scale. As for anthropocentrism, Benevolence (within Self-transcendence) correlates negatively, while Power (within Self-enhancement), Tradition and Security (within Conservatism) correlate positively (Schultz and Zelezny, 1999).

\subsection{Socio-demographic characteristics}

Socio-demographic characteristics as predictors of pro-environmental attitudes have been extensively researched. Although the results have not been very consistent across studies, when they are significant, education (positive), age (negative), political ideology (liberalism), as well as residence (urban), political party identification (Democratic in the US, i.e., to the left of the political spectrum), gender (female) and race (non-white) have most often been related to pro-environmental opinions (Dunlap, 2018: x). Other research supports these findings, too (Klineberg, McKeever and Rothenbach, 1998). When gender is a predictor, women tend to express stronger pro-environmental attitudes than men (Hadler and Wöhlkonig, 2012; Lewis, Palm and Feng, 2018). Research on the link between pro-environmental attitudes and age is much more inconsistent. Younger people tend to be more worried and concerned about environmental problems, but some findings suggest otherwise (Hadler and Wöhlkonig, 2012; Lewis et al., 2018). It seems that in most countries, progressive or leftist political parties show more concern about environmental issues than conservative or rightist parties (Franzen and Vogl, 2013; Lewis et al., 2018; Smith, Kim and Son, 2017). Higher education was also found to be a possible predictor of pro-environmental attitudes (Chaisty and Whitefield, 2015; Franzen and Meyer, 2010; Franzen and Vogl, 2013; Lewis et al., 2018; Smith et al., 2017). Lastly, pro-environmental behaviour also seems to increase with lower presented levels of religiosity (Lewis et al., 2018). 


\subsection{Environmental attitudes in Croatia and Central Europe}

Existing literature discusses the "ongoing distinctiveness" of post-communist/socialist countries "with respect to environmental attitudes" (Chaisty and Whitefield, 2015: 612). This most often relates to a lower level of environmentalism in Central and Eastern European countries (CEE), especially when compared to Western (WE) and Northern Europe (NE).

When looking at existing empirical data on different types of environmental attitudes, they mostly support this conclusion, although there are some individual divergences from the overall trend. Based on ISSP surveys, Chaisty and Whitefield (2015: 612) show that "post-Communist countries were and remain less supportive of environmentalism than advanced democracies". Regarding the environmental concern, the 2010 ISSP Environment III data reveal similarly low results for Eastern European (EE) countries, although Slovenia rates much higher than others (Guerra, Schmidt and Valente, 2018: 228). Regarding the environmental interest, the EVS results for 2017 show that all six of CE countries included in our analysis exhibit a low level of environmental interest, although Croatia and Slovenia rank higher than the Czech Republic, Hungary, Poland, and Slovakia (Nikodem and Trako Poljak, forthcoming). The ISSP 2010 data also show that citizens of the European semi-periphery are less willing to give up part of their income for environmental protection (Domazet and Ančić, 2018), as do EVS results that reveal a significant decrease in the desire to give up part of the income for environmental protection in these six CE countries over the last 20 years (between 1999 and 2017), although Croatia again ranks the highest, alongside Poland (Nikodem and Trako Poljak, forthcoming). However, some results show opposing trends, with these countries exhibiting a higher level of environmental awareness than WE and NE (Brajdić Vuković, 2014), and individual country results like those for Croatian citizens, for example, measure high scores on pro-environmental value orientations (Kufrin, 2014: 273). Some studies are, therefore, careful to warn that the argument made in some literature that "northern and western countries rank high on environmentalism vs. southern and eastern countries which rank lower" should be understood only as a tendency, which requires further research (Mayerl, 2018: 199, 200).

In our analysis, we focus on Croatia and compare it with five other CE countries (Czech Republic, Hungary, Poland, Slovakia and Slovenia), all members of the EU, with which it shares the geopolitical position, historical legacy and socio-cultural milieu. We also compare the results with NE and WE to see whether this argument of region-based similarities regarding environmentalism is supported by the item about the care for nature. In addition, we check for possible differences among 
individual CE countries, as well as between the FW (Czech Republic, Poland, Slovakia and Hungary) and FY (Croatia and Slovenia) subsamples. It should be noted that, while we rely on existing studies on different types of environmental attitudes discussed above in formulating our hypotheses, we are aware that they do not completely correspond to the item about the care for nature.

\section{METHODOLOGY}

\subsection{Samples and data collection}

All six CE countries in our cross-national comparison had participated in both ESS rounds: Round 4 (2008) and Round 9 (2018). The sizes of the probability samples are as follows: Round 4 (2008) included 31 countries with $\mathrm{N}=61009$ and Round 9 (2018) included 29 countries with $N=44$ 736. It should be noted that ESS data select new sample members for each round (cross-sectional sampling). To ensure comparability among different rounds of ESS data over time, all countries use random probability sampling, which means that everyone (aged 15 and over, residents within private households) have a chance to be selected (for more on sampling, data collection, and other methodological considerations, see: ESS Methodology Overview).

\subsection{Measurement instruments}

The item "He/She strongly believes that people should care for nature. Looking after the environment is important to him/her." measures the importance of caring for nature on a six-point scale (1=Not like me at all to 6=Very much like me). We focus on this item as it can be found in both rounds of the ESS (2008 and 2018) for all six CE countries; thus, we chose it as a dependent variable in our multiple regression analysis.

We correlate the environmental attitude item with Schwartz's HVS, excluding our dependent variable "care for nature" from the Universalism index of which it was originally part, so that we have 20 instead of 21 items that constitute 10 basic human values. All 21 items concerning basic human values are measured on a six-point scale (1=Not like me at all to 6=Very much like me $)^{1}$.

The socio-demographic characteristics of respondents are also correlated as independent variables and possible predictors of pro-environmental attitudes. These include basic demographic characteristics, such as gender (1=Male and 2=Fe-

In the original ESS coding lower scores signify that the value is more important for the respondents. 
male) and age (continuous variable); socio-economic variables, such as education level (from $1=$ No primary education to 5=Doctoral degree); and socio-cultural characteristics, such as religiosity (from $0=$ Not at all religious to $10=$ Very religious) and political beliefs on the left or right side of the scale (from $0=$ Left to 10=Right).

\subsection{Statistical data processing}

Statistical data processing was performed using the statistical program IBM SPSS Statistics 25. We used descriptive statistics and a Chi-square non-parametric test and multiple linear regression. All ESS methodological instructions were observed.

\subsection{Hypotheses}

Relying on the discussed studies on environmental attitudes in Croatia and other CE countries, as well as on the correlation between Schwartz's human values and socio-demographic characteristics with pro-environmentalism, we pose the following hypotheses:

$\mathrm{H} 1$ : Respondents in Croatia and five other CE countries moderately support the claim that people should care about nature, without much change between ESS Rounds 4 (2008) and 9 (2018);

$\mathrm{H}$ 2: Schwartz's human values predict the care for nature, with Universalism and Benevolence (within the higher-order value of Self-transcendence) being the strongest predictors in both ESS Rounds 4 (2008) and 9 (2018) for all six CE countries; and

H3: Respondents who are women, younger, higher educated, politically placed on the left, and less religious express a statistically significantly higher level of care for nature in both ESS Rounds 4 (2008) and 9 (2018) for all six CE countries, and vice versa. 


\section{RESULTS}

\subsection{Care for nature}

Table 1 shows that Hungary, Slovenia, and Poland had the highest perception of the importance of the care for nature in 2008, while the Czech Republic and Croatia had the lowest perception in the same year. Ten years later, in 2018, Slovenia and Croatia perceived the care for nature as the most important, while Hungary, the Czech Republic, and Poland had the lowest scores.

Based on the descriptive results, the comparison between the two ESS Rounds (2008 and 2018) reveals that three out of the six observed countries recorded an increase in the care for nature (strong in Croatia and Slovenia and slight in the Czech Republic); two countries had stable scores (Poland and Slovakia), and one country recorded a strong decrease (Hungary).

The two top answers for Croatia on the measuring scale for this item (Like me and Very much like me) increased from $63 \%$ of the respondents agreeing with these statements in 2008 to $80 \%$ in 2018 . On the contrary, Hungary recorded a major decline in the importance of the care for nature, with the top two answers on the measuring scale for this item (Like me and Very much like me) falling from $80 \%$ in 2008 to $65 \%$ in 2018.

Additionally, we wanted to compare two groups of CE countries, which we divided, on a territorial-historical basis, into former Warsaw pact countries (Czech Republic, Hungary, Poland, and Slovakia) and former Yugoslavian countries (Croatia and Slovenia). Here we can see that FW countries had a stable result between the two ESS rounds, while FY countries recorded a strong increase in the care for the environment.

When we conducted a simple chi-square test, we found six statistically significant correlations for the item "care for nature" in the two ESS rounds for these six countries (the only statistically non-significant chi-square was for the Czech Republic). ${ }^{2}$ Therefore, the results show that respondents in Croatia, Poland, Slovenia and Slovakia ${ }^{3}$ were statistically more inclined to prioritise care for nature in 2018

Chi-square statistics and their significance for all six observed countries: $X 2_{c z}=9.650 ; p_{c z}>0.05$; $\mathrm{X} 2_{\mathrm{HR}}=27.676 ; \mathrm{p}_{\mathrm{HR}}<0.01 ; \mathrm{X} 2_{\mathrm{HU}}=73.636 ; \mathrm{p}_{\mathrm{HU}}<0.01 ; \mathrm{X} 2_{\mathrm{PL}}=31.386 ; \mathrm{p}_{\mathrm{PL}}<0.01 ; \mathrm{X} 2_{\mathrm{SI}}=14.275 ;$ and $\mathrm{p}_{\mathrm{SI}}<0.05 ; \mathrm{x} 2_{\mathrm{sK}}=13.704 ; \mathrm{p}_{\mathrm{SK}}<0.05$

3 Even though Poland and Slovakia had a slightly higher mean in 2018 than in 2008, as well as a statistically significant Chi-square result if we look at the descriptive table and frequencies of answers for the item "care for nature", we see that the answers along the whole scale from 1 to 6 are quite similar. Therefore, it may be more correct to say that Poland and Slovakia had stable (and very similar) results in both ESS rounds, with no definite indication of their increase or decrease. 
than they were in 2008 , while in Hungary, the results are diametrically opposite the respondents in Hungary were statistically more inclined to prioritise care for nature in 2008 than in 2018.

Table 1. Cross-national description of the item "care for nature" (ESS Round 4, 2008; ESS Round 9, 2018)

\section{He/She strongly believes that people should care for nature. Looking after the environment is important to him/her.}

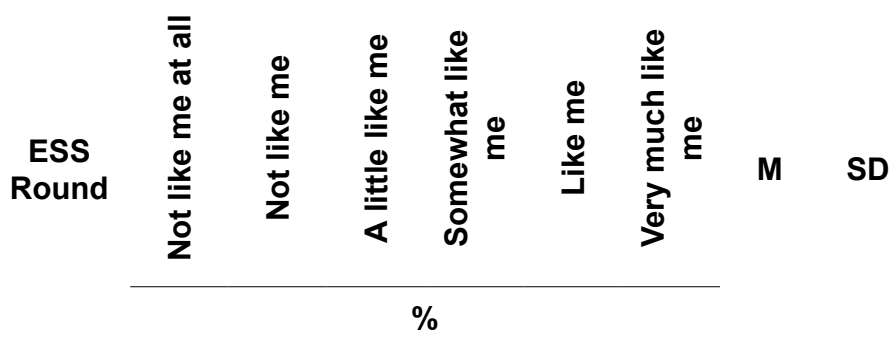

\begin{tabular}{cccccccccc}
\hline \multirow{2}{*}{ Czech Republic (CZ) } & $4(2008)$ & 1 & 4 & 10 & 26 & 36 & 24 & 4.65 & 1.10 \\
\cline { 2 - 9 } & $9(2018)$ & 1 & 2 & 10 & 22 & 35 & 30 & 4.78 & 1.09 \\
\hline \multirow{2}{*}{ Croatia (HR) } & $4(2008)$ & 1 & 3 & 12 & 22 & 37 & 26 & 4.67 & 1.13 \\
\cline { 2 - 9 } & $9(2018)$ & 0 & 2 & 5 & 13 & 41 & 39 & 5.08 & 0.97 \\
\hline \multirow{2}{*}{ Hungary (HU) } & $4(2008)$ & 0 & 1 & 3 & 15 & 39 & 41 & 5.14 & 0.92 \\
\cline { 2 - 9 } & $9(2018)$ & 1 & 4 & 10 & 20 & 40 & 25 & 4.69 & 1.13 \\
\hline \multirow{2}{*}{ Poland (PL) } & $4(2008)$ & 1 & 2 & 6 & 18 & 48 & 25 & 4.87 & 0.95 \\
\cline { 2 - 9 } & $9(2018)$ & 0 & 2 & 7 & 18 & 42 & 31 & 4.90 & 1.01 \\
\hline \multirow{2}{*}{ Slovenia (SI) } & $4(2008)$ & 0 & 2 & 4 & 15 & 46 & 32 & 4.99 & 0.97 \\
\cline { 2 - 8 } & $9(2018)$ & 0 & 1 & 2 & 8 & 40 & 49 & 5.34 & 0.81 \\
\hline \multirow{2}{*}{ Slovakia (SK) } & $4(2008)$ & 2 & 3 & 11 & 30 & 37 & 17 & 4.80 & 0.91 \\
\cline { 2 - 8 } & $9(2018)$ & 1 & 2 & 7 & 26 & 34 & 30 & 4.82 & 1.03 \\
\hline
\end{tabular}

\begin{tabular}{cccccccccc}
\hline $\begin{array}{c}\text { Central Europe - all } \\
\text { six countries (CE) }\end{array}$ & $4(2008)$ & 0 & 2 & 7 & 20 & 44 & 27 & 4.86 & 0.99 \\
\cline { 2 - 8 } & $9(2018)$ & 1 & 2 & 7 & 19 & 40 & 31 & 4.87 & 1.04 \\
\hline $\begin{array}{c}\text { Former Warsaw pact } \\
\text { countries (FW) }\end{array}$ & $4(2008)$ & 1 & 2 & 6 & 20 & 44 & 27 & 4.87 & 0.98 \\
\cline { 2 - 8 } & $9(2018)$ & 1 & 2 & 8 & 20 & 40 & 29 & 4.84 & 1.05 \\
\hline $\begin{array}{c}\text { Former Yugoslavian } \\
\text { countries (FY) }\end{array}$ & $4(2008)$ & 1 & 3 & 9 & 19 & 40 & 28 & 4.77 & 1.09 \\
\cline { 2 - 8 } & $9(2018)$ & 0 & 2 & 4 & 11 & 40 & 43 & 5.17 & 0.92 \\
\hline
\end{tabular}


Regarding the two country blocks, despite statistically significant correlation for the item "care for nature" in FW countries between the two ESS rounds ( $\mathrm{X} 2_{\mathrm{FW}}=$ 29.297; $\left.\mathrm{p}_{\mathrm{FW}}<0.01\right)$, a deeper look into the results shows that the care for nature is stable over the 10-year period. On the other hand, $F Y$ countries $\left(X 2_{F Y}=41.462\right.$; $\mathrm{p}_{\mathrm{FY}}<0.01$ ) were statistically more inclined to prioritise care for nature in 2018 than they were in 2008.

In total, for the combined sample of CE countries, we did find statistically significant correlations for the item "care for nature" between the two ESS rounds ( $\mathrm{X}{ }_{\mathrm{CE}}$ $=28.757 ; p_{C E}>0.01$ ), but a deeper look into the results shows that FW countries exhibit stable results over the 10-year period, except Hungary, which shows a significant decline in its scores, while FY countries move to the top, with Slovenia rising slightly and Croatia showing a significant rise in 2018.

Table 2. Additional cross-regional description of the item "care for nature" (ESS Round 4, 2008; ESS Round 9, 2018)

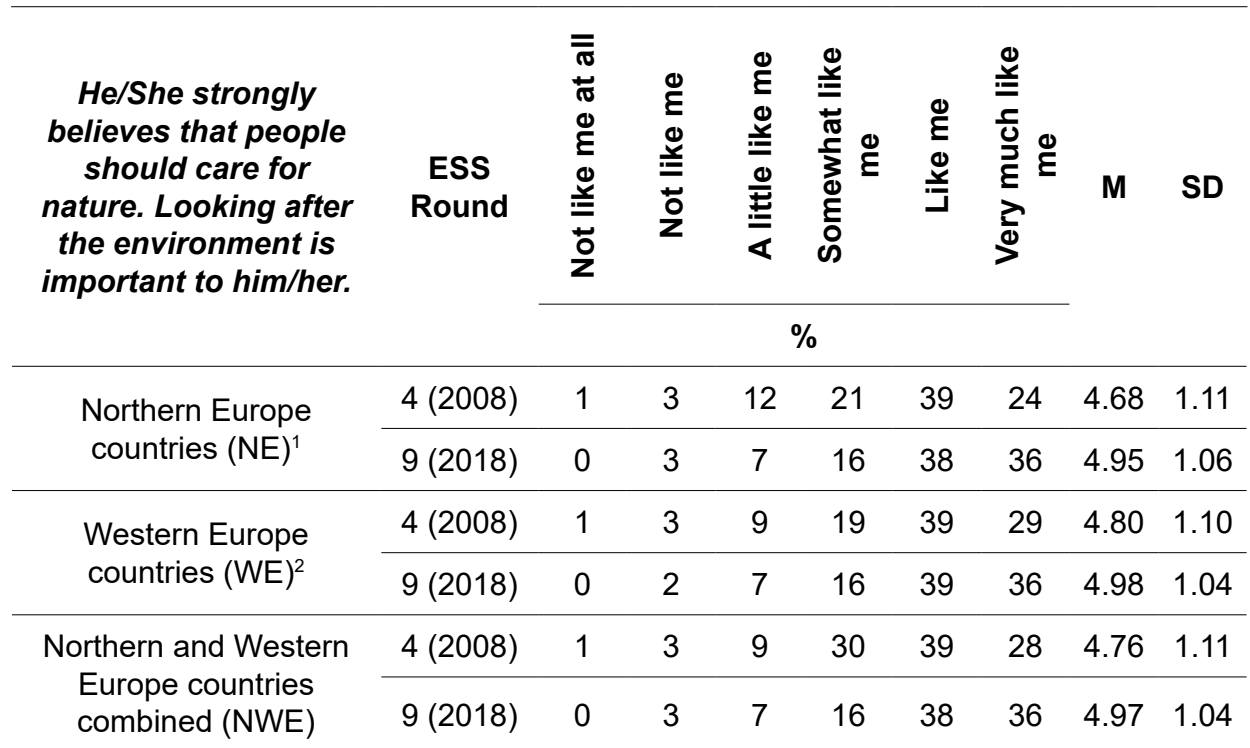

1 The countries included in the NE sample are Denmark, Finland, Ireland, Norway, Sweden, and the United Kingdom

2 The countries included in the WE sample are Austria, Belgium, France, Germany, Netherlands, and Switzerland.

Table 2 presents the results for NE and WE countries. CE countries have a similarly moderate mean score for the care for nature in 2008 as NE and WE countries, but the results are just the opposite in 2018, with NE and WE countries having higher mean scores than CE countries, whose score remains the same. However, 
when we look at our subsamples, while the mean for FW countries corresponds to the overall CE trend, with even a slight decline in 2018, the two FY countries exhibit a rise in the mean score by 2018 , which is now also the highest compared to FW as well as NE and WE countries.

\subsection{Schwartz's Human Values Scale}

Tables 3 and 4 present the descriptive results (centred means and standard deviations) for Schwartz's 10 basic human values for the six CE countries, as well as two country blocks, in the two ESS rounds (2008 and 2018). In general, in all six countries, across both ESS rounds, Benevolence, Security, and Universalism were the most expressed basic human values, while Stimulation, Hedonism and Power were expressed the least.

In both ESS rounds, Self-direction was most expressed by the respondents in the Czech Republic, and least expressed by those in Croatia and Poland. Stimulation, Achievement, and Power were the basic values that respondents in all countries were not inclined to at all, in either ESS round. Respondents were not inclined to Hedonism either, except in Hungary. Security was most expressed by respondents in Slovakia, Croatia, and Hungary, while it was least expressed by those in Slovenia. The respondents were mostly not inclined to Conformity, except in Poland and Slovakia. Across both ESS rounds, Tradition was most expressed by respondents in Poland, Slovakia, and Slovenia, and least expressed by those in the Czech Republic. Benevolence and Universalism were both most expressed by respondents in Croatia, while it was least expressed by those from the Czech Republic in both ESS rounds.

Additionally, in both ESS rounds, FW countries are more inclined to express Stimulation, Power, and Conformity, while FY countries are more inclined to express Hedonism, Achievement, Benevolence, and Universalism, while the results for other basic human values are quite similar in both country blocks in both ESS rounds. 
Table 3. Centred mean values and standard deviation for basic human values (1/2) (ESS Round 4, 2008; ESS Round 9, 2018)

\begin{tabular}{|c|c|c|c|c|c|c|c|c|c|c|c|}
\hline \multirow{2}{*}{ Country } & \multirow{2}{*}{$\begin{array}{c}\text { ESS } \\
\text { Round }\end{array}$} & \multicolumn{2}{|c|}{$\begin{array}{c}\text { Self- } \\
\text { direction }\end{array}$} & \multicolumn{2}{|c|}{ Stimulation } & \multicolumn{2}{|c|}{ Hedonism } & \multicolumn{2}{|c|}{ Achievement } & \multicolumn{2}{|c|}{ Power } \\
\hline & & $\mathrm{CM}$ & SD & $\mathrm{CM}$ & SD & $\mathrm{CM}$ & SD & $\mathrm{CM}$ & SD & CM & SD \\
\hline \multirow{2}{*}{$\mathrm{CZ}$} & $4(2008)$ & 0.42 & 0.75 & -0.70 & 1.00 & -0.31 & 1.00 & -0.48 & 0.96 & -0.47 & 0.85 \\
\hline & $9(2018)$ & 0.33 & 0.70 & -0.57 & 0.98 & -0.21 & 0.88 & -0.46 & 0.90 & -0.35 & 0.83 \\
\hline \multirow{2}{*}{ HR } & $4(2008)$ & 0.20 & 0.81 & -1.14 & 1.15 & -0.49 & 1.04 & -0.24 & 0.92 & -0.68 & 0.87 \\
\hline & $9(2018)$ & 0.23 & 0.80 & -1.16 & 1.10 & -0.34 & 0.91 & -0.38 & 0.97 & -0.96 & 0.89 \\
\hline \multirow{2}{*}{$\mathrm{HU}$} & $4(2008)$ & 0.29 & 0.74 & -0.85 & 1.05 & 0.07 & 0.77 & -0.22 & 0.86 & -0.79 & 0.92 \\
\hline & $9(2018)$ & 0.33 & 0.73 & -0.72 & 1.01 & 0.08 & 0.77 & -0.15 & 0.86 & -0.58 & 0.87 \\
\hline \multirow{2}{*}{ PL } & $4(2008)$ & 0.21 & 0.78 & -0.74 & 0.92 & -0.90 & 1.08 & -0.33 & 0.86 & -0.61 & 0.89 \\
\hline & $9(2018)$ & 0.15 & 0.76 & -0.87 & 0.97 & -0.98 & 1.08 & -0.32 & 0.87 & -0.49 & 0.92 \\
\hline \multirow{2}{*}{ S } & $4(2008)$ & 0.30 & 0.71 & -0.58 & 0.97 & -0.06 & 0.91 & -0.11 & 0.77 & -0.91 & 0.83 \\
\hline & $9(2018)$ & 0.31 & 0.69 & -0.74 & 0.97 & -0.22 & 0.91 & -0.10 & 0.76 & -1.13 & 0.79 \\
\hline \multirow{2}{*}{ SK } & $4(2008)$ & 0.20 & 0.68 & -0.79 & 0.87 & -0.94 & 1.04 & -0.22 & 0.81 & -0.47 & 0.77 \\
\hline & $9(2018)$ & 0.31 & 0.66 & -0.67 & 0.91 & -0.42 & 0.84 & -0.25 & 0.84 & -0.51 & 0.86 \\
\hline \multirow{2}{*}{ CE } & $4(2008)$ & 0.25 & 0.77 & -0.77 & 0.97 & -0.63 & 1.08 & -0.32 & 0.88 & -0.62 & 0.89 \\
\hline & $9(2018)$ & 0.22 & 0.74 & -0.80 & 0.99 & -0.61 & 1.07 & -0.31 & 0.88 & -0.53 & 0.90 \\
\hline \multirow{2}{*}{ FW } & $4(2008)$ & 0.26 & 0.76 & -0.75 & 0.95 & -0.66 & 1.09 & -0.33 & 0.88 & -0.60 & 0.89 \\
\hline & $9(2018)$ & 0.22 & 0.74 & -0.78 & 0.98 & -0.64 & 1.08 & -0.31 & 0.87 & -0.48 & 0.89 \\
\hline \multirow{2}{*}{$\mathrm{FY}$} & $4(2008)$ & 0.23 & 0.78 & -0.96 & 1.12 & -0.35 & 1.02 & -0.20 & 0.88 & -0.75 & 0.87 \\
\hline & 9 (2018) & 0.26 & 0.77 & -1.01 & 1.08 & -0.29 & 0.91 & -0.28 & 0.91 & -1.02 & 0.86 \\
\hline
\end{tabular}


Table 4. Centred mean values and standard deviation for basic human values (2/2) (ESS Round 4, 2008; ESS Round 9, 2018)

\begin{tabular}{|c|c|c|c|c|c|c|c|c|c|c|c|}
\hline \multirow{2}{*}{ Country } & \multirow{2}{*}{$\begin{array}{l}\text { ESS } \\
\text { Round }\end{array}$} & \multicolumn{2}{|c|}{ Security } & \multicolumn{2}{|c|}{ Conformity } & \multicolumn{2}{|c|}{ Tradition } & \multicolumn{2}{|c|}{ Benevolence } & \multicolumn{2}{|c|}{ Universalism } \\
\hline & & CM & SD & CM & SD & CM & SD & CM & SD & CM & SD \\
\hline \multirow{2}{*}{$C Z$} & $4(2008)$ & 0.59 & 0.85 & & 0.91 & -0.11 & 0.99 & 0.40 & 0.68 & 0.39 & 0.63 \\
\hline & 9 (2018) & 0.64 & 0.84 & -0.07 & 0.83 & -0.04 & 0.88 & 0.33 & 0.69 & 0.26 & 0.60 \\
\hline \multirow{2}{*}{ HR } & $4(2008)$ & 0.75 & 0.81 & -0.05 & 0.94 & 0.17 & 1.03 & 0.74 & 0.66 & 0.49 & 0.67 \\
\hline & $9(2018)$ & 0.59 & 0.77 & -0.04 & 0.87 & 0.17 & 0.93 & 0.85 & 0.63 & 0.69 & 0.60 \\
\hline \multirow{2}{*}{$\mathrm{HU}$} & $4(2008)$ & 0.72 & 0.71 & -0.41 & 0.95 & 0.06 & 0.94 & 0.54 & 0.63 & 0.40 & 0.58 \\
\hline & $9(2018)$ & 0.53 & 0.79 & -0.31 & 0.88 & -0.04 & 0.86 & 0.44 & 0.73 & 0.28 & 0.62 \\
\hline \multirow{2}{*}{ PL } & $4(2008)$ & 0.52 & 0.73 & 0.26 & 0.79 & 0.21 & 0.83 & 0.54 & 0.59 & 0.56 & 0.58 \\
\hline & 9 (2018) & 0.66 & 0.80 & 0.21 & 0.85 & 0.23 & 0.93 & 0.58 & 0.62 & 0.54 & 0.58 \\
\hline \multirow{2}{*}{ SI } & $4(2008)$ & 0.38 & 0.73 & -0.23 & 0.86 & 0.14 & 0.82 & 0.42 & 0.57 & 0.44 & 0.55 \\
\hline & $9(2018)$ & 0.51 & 0.71 & -0.22 & 0.93 & 0.25 & 0.82 & 0.49 & 0.57 & 0.56 & 0.52 \\
\hline \multirow{2}{*}{ SK } & $4(2008)$ & 0.75 & 0.74 & 0.25 & 0.80 & 0.14 & 0.97 & 0.43 & 0.67 & 0.44 & 0.56 \\
\hline & $9(2018)$ & 0.62 & 0.79 & -0.02 & 0.81 & 0.77 & 1.02 & 0.30 & 0.63 & 0.37 & 0.58 \\
\hline \multirow{2}{*}{ CE } & $4(2008)$ & 0.59 & 0.76 & 0.11 & 0.88 & 0.13 & 0.90 & 0.52 & 0.62 & 0.49 & 0.59 \\
\hline & $9(2018)$ & 0.62 & 0.80 & 0.50 & 0.87 & 0.14 & 0.93 & 0.51 & 0.66 & 0.46 & 0.60 \\
\hline \multirow{2}{*}{ FW } & $4(2008)$ & 0.58 & 0.76 & 0.13 & 0.87 & 0.13 & 0.90 & 0.51 & 0.62 & 0.49 & 0.60 \\
\hline & $9(2018)$ & 0.63 & 0.80 & 0.06 & 0.87 & 0.13 & 0.93 & 0.49 & 0.66 & 0.44 & 0.60 \\
\hline \multirow{2}{*}{ FY } & $4(2008)$ & 0.61 & 0.81 & -0.11 & 0.92 & 0.15 & 0.96 & 0.64 & 0.66 & 0.47 & 0.64 \\
\hline & $9(2018)$ & 0.56 & 0.75 & -0.10 & 0.90 & 0.20 & 0.90 & 0.73 & 0.63 & 0.64 & 0.58 \\
\hline
\end{tabular}

Table 5 presents the descriptive results for four higher-order values for the six CE countries, as well as the two country blocks, in the two ESS rounds. In general, in all the observed countries and in both ESS rounds, Self-transcendence was the most expressed higher-order value. According to the descending mean, Conservatism was the second most expressed higher-order value, followed by Openness to change, while the least expressed higher-order value was Self-enhancement. 
Table 5. Mean values and standard deviation for higher-order values (ESS Round 4, 2008; ESS Round 9, 2018)

\begin{tabular}{|c|c|c|c|c|c|c|c|c|c|}
\hline \multirow{2}{*}{ Country } & \multirow{2}{*}{$\begin{array}{l}\text { ESS } \\
\text { Round }\end{array}$} & \multicolumn{2}{|c|}{$\begin{array}{c}\text { Openness to } \\
\text { change }\end{array}$} & \multicolumn{2}{|c|}{ Conservatism } & \multicolumn{2}{|c|}{$\begin{array}{c}\text { Self- } \\
\text { transcendence }\end{array}$} & \multicolumn{2}{|c|}{$\begin{array}{c}\text { Self- } \\
\text { enhancement }\end{array}$} \\
\hline & & M & SD & M & SD & M & SD & M & SD \\
\hline \multirow{2}{*}{$\mathrm{CZ}$} & $4(2008)$ & 3.93 & 0.91 & 4.31 & 0.79 & 4.51 & 0.75 & 3.65 & 1.03 \\
\hline & $9(2018)$ & 4.06 & 0.86 & 4.38 & 0.75 & 4.49 & 0.74 & 3.80 & 0.98 \\
\hline \multirow{2}{*}{$\mathrm{HR}$} & $4(2008)$ & 3.70 & 1.06 & 4.46 & 0.81 & 4.76 & 0.75 & 3.72 & 1.09 \\
\hline & 9 (2018) & 3.84 & 0.90 & 4.51 & 0.80 & 5.02 & 0.71 & 3.60 & 0.95 \\
\hline \multirow{2}{*}{$\mathrm{HU}$} & $4(2008)$ & 4.20 & 0.84 & 4.48 & 0.73 & 4.82 & 0.71 & 3.85 & 0.97 \\
\hline & 9 (2018) & 4.04 & 0.84 & 4.21 & 0.75 & 4.49 & 0.79 & 3.78 & 1.01 \\
\hline \multirow{2}{*}{ PL } & 4 (2008) & 3.78 & 0.90 & 4.58 & 0.74 & 4.80 & 0.65 & 3.78 & 0.90 \\
\hline & $9(2018)$ & 3.55 & 0.87 & 4.49 & 0.77 & 4.68 & 0.73 & 3.71 & 0.90 \\
\hline \multirow{2}{*}{ SI } & $4(2008)$ & 4.31 & 0.82 & 4.50 & 0.75 & 4.86 & 0.63 & 3.92 & 0.84 \\
\hline & $9(2018)$ & 4.36 & 0.82 & 4.76 & 0.69 & 5.11 & 0.52 & 3.97 & 0.78 \\
\hline \multirow{2}{*}{ SK } & $4(2008)$ & 3.79 & 0.95 & 4.68 & 0.67 & 4.74 & 0.63 & 3.96 & 0.96 \\
\hline & 9 (2018) & 4.00 & 0.87 & 4.48 & 0.72 & 4.60 & 0.70 & 3.88 & 1.00 \\
\hline \multirow{2}{*}{ CE } & $4(2008)$ & 3.87 & 0.92 & 4.53 & 0.75 & 4.75 & 0.69 & 3.79 & 0.95 \\
\hline & $9(2018)$ & 3.77 & 0.90 & 4.44 & 0.77 & 4.65 & 0.75 & 3.75 & 0.94 \\
\hline \multirow{2}{*}{$\mathrm{FW}$} & $4(2008)$ & 3.87 & 0.91 & 4.53 & 0.75 & 4.75 & 0.69 & 3.79 & 0.94 \\
\hline & $9(2018)$ & 3.75 & 0.90 & 4.42 & 0.77 & 4.61 & 0.74 & 3.75 & 0.94 \\
\hline \multirow{2}{*}{$\mathrm{FY}$} & $4(2008)$ & 3.89 & 1.03 & 4.48 & 0.79 & 4.80 & 0.71 & 3.78 & 1.02 \\
\hline & $9(2018)$ & 4.02 & 0.91 & 4.59 & 0.78 & 5.05 & 0.65 & 3.73 & 0.91 \\
\hline
\end{tabular}

In both rounds, the higher-order value of Openness to change was most expressed by respondents in Slovenia, while it was least expressed by those in Croatia and Poland (in Croatia, the value was increasing, while in Poland it was decreasing). Respondents from Slovenia and Slovakia were mostly inclined to express Conservatism (in Slovenia, the value was increasing, while in Slovakia it was decreasing), while respondents from the Czech Republic were least inclined to it. Self-transcendence was most expressed by respondents in Slovenia and least expressed by those in the Czech Republic, Hungary, and Poland. Lastly, Self-enhancement 
was most expressed by respondents in Slovenia and Slovakia, while it was least expressed by those in the Czech Republic and Croatia (in the Czech Republic, the value was increasing, while in Croatia it was decreasing).

Additionally, in both ESS rounds, FY countries are more inclined to express Openness to change and Self-transcendence, while for the two other higher-order values the results are quite similar in both country blocks, in both ESS rounds.

\subsection{Basic values and socio-demographics as predictors of the care for nature}

We conducted multiple linear regression analysis for all six observed CE countries, as well as the two country blocks and the whole sample of six CE countries combined, in the two ESS rounds, using the item "important to care for nature and environment" as the criterion (i.e., the dependent variable), and basic human values, as well as socio-demographic characteristics, as predictors (Table 6 and 7). 


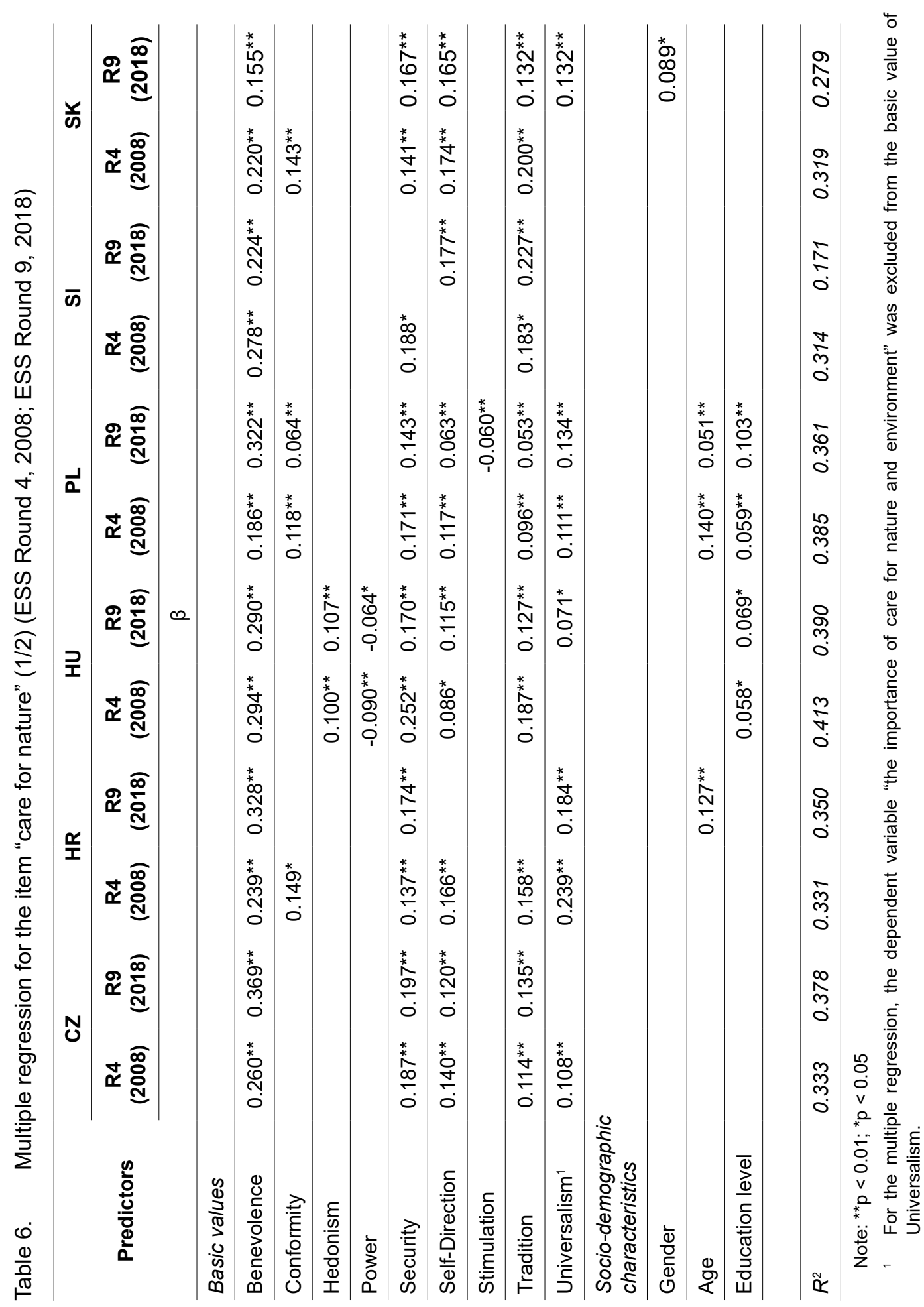


Table 7. Multiple regression for the item "care for nature" (2/2) (ESS Round 4, 2008; ESS Round 9, 2018)

\begin{tabular}{|c|c|c|c|c|c|c|}
\hline \multirow{3}{*}{ Predictors } & \multicolumn{2}{|c|}{ CE } & \multicolumn{2}{|c|}{ FW } & \multicolumn{2}{|c|}{ FY } \\
\hline & R4 (2008) & R9 (2018) & R4 (2008) & R9 (2018) & R4 (2008) & R9 (2018) \\
\hline & \multicolumn{6}{|c|}{$\beta$} \\
\hline \multicolumn{7}{|l|}{ Basic values } \\
\hline Benevolence & $0.288^{* *}$ & $0.316^{\star *}$ & $0.308^{\star *}$ & $0.325^{\star *}$ & $0.170^{\star *}$ & $0.249^{\star *}$ \\
\hline Conformity & $0.054^{* *}$ & $0.067^{* *}$ & $0.045^{\star *}$ & $0.081^{* *}$ & & \\
\hline Hedonism & $0.054^{* *}$ & & $0.066^{\star *}$ & & & \\
\hline Power & $-0.037^{* *}$ & & $-0.034^{* *}$ & & & \\
\hline Security & $0.177^{* *}$ & $0.156^{\star *}$ & $0.184^{\star *}$ & $0.154^{* *}$ & $0.140^{* *}$ & $0.151^{\star *}$ \\
\hline Self-Direction & $0.095^{\star *}$ & $0.098^{* *}$ & $0.092^{* \star}$ & $0.103^{* *}$ & $0.191^{* *}$ & $0.114^{* *}$ \\
\hline Stimulation & & $-0.036^{* *}$ & $-0.038^{*}$ & $-0.048^{* *}$ & & \\
\hline Tradition & $0.144^{* *}$ & $0.091^{* *}$ & $0.128^{* *}$ & $0.075^{* *}$ & $0.243^{* *}$ & $0.124^{* *}$ \\
\hline Universalism ${ }^{1}$ & $0.089^{* *}$ & $0.093^{* *}$ & $0.092^{\star *}$ & $0.075^{\star *}$ & $0.114^{*}$ & $0.146^{\star *}$ \\
\hline
\end{tabular}

Socio-demographic

characteristics

\begin{tabular}{|c|c|c|c|}
\hline Gender & & $-0.025^{*}$ & \\
\hline Age & $0.080^{* *}$ & $0.076^{\star \star}$ & $0.113^{* *}$ \\
\hline Religiosity & $-0.048^{* *}$ & $-0.037^{* *}$ & \\
\hline
\end{tabular}

\begin{tabular}{lllllll}
\hline$R^{2}$ & 0.364 & 0.350 & 0.371 & 0.341 & 0.322 & 0.324 \\
\hline
\end{tabular}

Note: ${ }^{* *} \mathrm{p}<0.01 ;{ }^{*} \mathrm{p}<0.05$

1 For the multiple regression, the dependent variable "the importance of care for nature and environment" was excluded from the basic value of universalism.

The results reveal that basic human values and the respondents' socio-demographic characteristics were solid predictors of the care for nature in both ESS rounds, with quite similar percentages of explained variance in both ESS rounds (36.4\% in 2008 and $35.0 \%$ in 2018). The strongest prediction model in 2008 was found in Hungary (41.3\% of the explained variance), and the weakest were in Slovenia (31.4\%) and Slovakia (31.9\%). Similar percentages of the explained variance were found in 2018 as well, with Hungary again having the strongest predictive model $(39.0 \%)$, and Slovenia $(17.1 \%)$ having the weakest. Comparing the predictive 
models for the 10-year period, basic human values and chosen individual characteristics had better predictability in 2008 for Slovenia, and Slovakia; predictability was very similar in both rounds for Croatia, Hungary and Poland, while the Czech Republic had better predictabilities in 2018.

Among the basic human values, the most statistically significant predictor for expressing care for nature was Benevolence, which was the strongest basic value predictor on the whole sample of six observed CE countries in both rounds. It was also the only predictor that was statistically significant in all the examined countries and rounds. Furthermore, in 2018, Benevolence was not the strongest predictor of care for the environment only in Slovenia and Slovakia. The positive beta coefficient shows that respondents who are prone to expressing benevolent values attached more importance to the care for nature.

Yet, Universalism, which we assumed would be one of the strongest basic value predictors of the care for nature, alongside Benevolence, with which it shares the higher-order value of Self-transcendence, has turned out to be a weaker predictor. In the whole sample of six observed countries, Universalism is a significant predictor of care for the environment, but its predictability strength is low $\left(\beta_{C E}(2008)\right.$ $\left.=0.089 ; \beta_{C E}(2018)=0.093\right)$. As for the statistical significance in the six observed countries, Universalism is not a statistically significant predictor in either ESS rounds in Slovenia, or in Hungary and Slovakia in 2008, or the Czech Republic in 2018. However, the positive beta coefficient shows that respondents who are prone to expressing universalistic values do attach more importance to the care for nature.

Additionally, we compared regression models for the two country blocks and, in both ESS rounds, FW countries had slightly higher percentages of the explained variance. In FW countries, Benevolence is the strongest predictor of care for the environment in both ESS rounds, with those who are prone to expressing benevolent values attributing more importance to the care for nature. Furthermore, Universalism is a significant, but weak predictor in both ESS rounds for FW countries. On the other hand, in FY countries Benevolence is the strongest predictor of care for nature only in 2018, while Security and Tradition are stronger predictors in 2008. Besides, Universalism is a much weaker predictor of care for the environment than it was in FW countries. However, if we correlate this finding with the significant rise of care for nature in FY countries between the two ESS rounds, the rise in significance of Benevolence was expected. In addition, in these countries, Universalism is a much better predictor of care for nature than it was in FW countries.

The socio-demographic characteristics were much less predictive than the basic values. In the whole sample of CE countries, age and religiosity were the only individual characteristics that were significant predictors of the care for na- 
ture. Furthermore, age was a statistically significant predictor in the subsamples of two countries (Croatia in 2008 and Poland in both rounds). The positive beta coefficient shows that older respondents attached more importance to the care for nature, which was opposite to the widely accepted assumption about young people's pro-environmental attitudes. Religiosity is a weak predictor in the whole sample (non-significant in all six country sub-samples) and, from the negative beta coefficient, we can conclude that respondents with higher religiosity attached less importance to the care for nature. Even though it was not significant in the whole sample, education level turned out to be a solid predictor in two countries in both rounds (Hungary and Poland). The positive beta coefficient shows that respondents with higher education levels attributed more importance to the care for nature. Lastly, gender was found to be a significant, albeit weak predictor only in Slovakia in 2018, and the positive beta coefficient shows that women attached more importance to the care for nature. Political orientation was not a significant predictor of the care for nature.

\section{DISCUSSION}

Our first hypothesis $(\mathrm{H} 1)$ stating that respondents in Croatia and five other $\mathrm{CE}$ countries moderately support the claim that people should care about nature, without much change between ESS Rounds 4 (2008) and 9 (2018), was only partially confirmed. We found a moderate to a moderately strong agreement among six CE countries that people should care for nature and that looking after the natural environment is important for them both in $2008(M=4.86)$ and $2018(M=4.87)$. A comparison with WE and NE countries shows that in 2008 WE, NE and CE countries all exhibited a similarly moderately high level of support for the care for nature (with NE countries scoring the lowest). However, by 2018, there was a shift toward stronger support for the care for nature in WE and NE countries (with comparable scores), with the CE countries showing stagnation in the results. These results seem to support our hypothesis, with overall lower scores for the care for nature in CE countries and little change over time, albeit somewhat more positive than our initial assumption.

However, when looking more closely at the FW and FY subsamples, while FW countries show moderate and unchanging support for the care for nature, FY countries (Croatia and Slovenia) exhibit a significant increase in the results for the care for nature in 2018, surpassing even the WE and NE countries $(M=5.17)$. Croatia is particularly interesting as it had one of the lowest scores in 2008 , but while Slovakia, Poland and the Czech Republic had not shifted much from their position by 2018, Croatia took second place among the CE countries, being surpassed only 
by Slovenia, which moved from the second to the top position. The most surprising results are certainly those relating to Hungary, which went from the highest score regarding the perception of the care for nature in 2008 to the lowest in 2018. Therefore, while these results are in line with existing studies that demonstrate overall similar trends in environmental attitudes in CE countries, especially when compared to WE and NE, they also indicate that some countries diverge from the overall CEE trend in this aspect of pro-environmentalism about the care for nature. The results for Croatia and Slovenia are in line with some existing studies that show these countries diverging from the overall CEE trends, with a higher environmental interest in Slovenia (Guerra et al., 2018: 228), higher environmental awareness in Croatia (Brajdić Vuković, 2014), as well as strong pro-environmental value orientations in Croatia (Kufrin, 2014: 273), and higher results for environmental interest in both Croatia and Slovenia (Nikodem and Trako Poljak, forthcoming). As for Hungary, the significant decrease in the support for the care for nature seems to be in line with the reports according to which the environment was not a salient topic following the post-2008 economic recovery (Mikecz, 2017) but these reasons require further examination.

Our second hypothesis $(\mathrm{H} 2)$, stating that Schwartz's human values prove to be predictors of the care for nature, with Universalism and Benevolence (within the higher-order value of Self-transcendence) being the strongest predictors, was confirmed for all six CE countries in both ESS Rounds 4 (2008) and 9 (2018). The basic value of Benevolence was a much stronger predictor than Universalism, which is interesting as the item "care for nature" was originally part of the Universalism index. Among other values, the most prevalent predictors for CE countries were the basic values of Security and Tradition (Conservatism) and Self-direction (the only predictive within the higher-order value of Openness to change). The higher-order value of Self-enhancement was not a good predictor of the care for nature for most countries. Some specific, albeit weak, predictors were found for individual countries, such as Hedonism and, negatively, Power (Self-enhancement) for Hungary in 2008 and 2018, and Conformity (Conservatism) for Croatia and Slovakia in 2008 and Poland in 2008 and 2018.

These results are mostly in line with previous studies showing that Self-transcendence is connected to pro-environmentalism the most and Self-enhancement the least (Schultz and Zelezny 1999; Stern, 1999). The higher-order value of Self-transcendence "reflects a broader cognitive representation of self, and measures the degree to which a person includes other people and other living things in their notion of self" (Schultz and Zelezny, 1999: 263), so it is not surprising that its basic values correlate the most with the care for nature. Ecocentrism does imply being able to "transcend oneself", put egoistic and selfish interests aside and show 
compassion and care for fellow beings (which can be extended to the "co-world", consisting of people, animals, plants and the ecosystem) (for the empirical connection between ecocentrism and the care ethics, see Trako Poljak et al., 2018). The result according to which self-enhancement is no predictor of the care for nature also supports previous findings as the goals that promote own interests regardless of others are very much not in line with the care for nature. As for other value predictors, although the results of previous studies are less clear, contrary to Schultz and Zelezny (2003), who show that Conservatism is negatively related to environmental concern, our results show that it is positively related to the care for nature. In Schwartz's model, Conservatism comprises values related to social stability and tradition (Schultz and Zelezny, 2003; Schwartz, 1994), so it may be surprising that it also predicts the care for nature. However, as some authors show, in Schwartz's model, Self-transcendence and Conservatism both relate to the social or collective dimension vs. Self-enhancement and Openness to change, which relate to the individual value types (Kapoor, Wolfe and Blue, 1995; Rudnev, Magun and Schwartz, 2018). Therefore, it seems that pro-environmentalism could be related to the values that promote the sense of communalism vs. individualism for these six CE countries. The finding for Self-direction, relating to creativity and freedom, is interesting and, although it belongs to the more individualistic dimension of Openness to change, it may indicate the willingness to extend the same freedom to the co-world and support its diversity.

However, despite the commonalities regarding the relationship between Schwartz's human values and the care for nature in the selected CE countries, when looking at the subsamples, FW countries are more inclined to express Stimulation, Power and Conformity (belonging to all higher-order values but Self-transcendence), while Self-transcendence is slightly decreasing, unlike in FY countries. Croatia and Slovenia, who exhibit the highest care for nature over the 10-year period, also scored the highest on the value of Self-transcendence. Hungary, as the only country that shows the opposite trend, also exhibits low and decreasing Self-transcendence values over time. These findings, suggesting that the same countries that diverge from the overall CEE trend regarding the care for nature also diverge regarding the same predictive values for the care for nature, confirm that Schwartz's HVS can be predictive of pro-environmentalism in CE countries while offering a new dimension for the interpretation of environmental attitudes in these countries. As for the socio-demographic predictors, our hypothesis $(\mathrm{H} 3)$ was not confirmed. While no socio-demographic characteristics proved to be strong predictors, some unexpected results were obtained. There are some indications that older respondents attached more importance to the care for nature, which is contrary to the widespread assumption that younger people are more invested in pro-envi- 
ronmentalism (although some studies support these opposing results, e.g., Hadler and Wöhlkonig, 2012; Lewis et al., 2018). Besides, in our sample, people who are religious attribute less importance to the care for nature, while the higher educated (only in Hungary and Poland) and women (only in Slovakia) attributed more importance. As the results are inconsistent and mostly not statistically significant, we will not draw any concrete conclusions regarding socio-demographics as predictors of the care for nature.

\section{CONCLUSION}

As the world is facing extensive consequences of the global social-ecological crisis, measuring environmental attitudes and gaining a better understanding of their predictors have become critically important. Previous research focused more on external (social, political and economic) factors and, when values are considered, large social surveys mostly employed Inglehart's materialist/postmaterialist model. We examined environmental attitudes, conceptualised as the care for nature in the European Social Survey in Croatia and, comparatively, in five other CE countries (Czech Republic, Hungary, Poland, Slovenia, and Slovakia), over the 10-year period (2008 and 2018). We also looked at whether other values models, like Schwartz's HVS, which is used in the ESS, can provide further insight.

Future research should look deeper into our findings as there are limits to our analysis. For example, positive results, especially for Croatia and Slovenia, do not necessarily translate into pro-environmental behaviour, especially as the formulation of the item about the care for nature in the ESS is quite prospective and non-obligatory ("should care", "environment is important"). Secondly, other variables besides Schwartz's human values should be investigated. For example, the relationship between Inglehart and Schwartz's values models has been examined in other studies but could be interesting to compare regarding pro-environmentalism in these CE and other countries as well. Finally, our definition of the sample as $C E$ was based on the existing literature pointing to their similarities, including environmental attitudes. However, our research revealed differences between the two subsamples (FY and FW countries) as well as individual countries, so future research that would compare these results with other European countries in the West, North and South and provide further explanation of these differences would also be useful.

To sum up, our findings indicate that while there are similar trends regarding environmental attitudes conceptualised as the care for nature in the ESS between Croatia and other CE countries, especially when compared to WE and NE countries, there are some differences as well. Overall, the situation seems to be im- 
proving regarding pro-environmental values in Croatia and Slovenia, at least regarding the item on the care for nature, and this seems to be connected to a rise in Self-transcendence values in particular, while more efforts could be made to enhance the care for nature in Slovakia, Poland and the Czech Republic, with the situation in Hungary being most concerning. Our goal to see whether these similarities and differences could be explained by Schwartz's model of human values, which had not been employed previously when examining environmental attitudes in Croatia, has been achieved satisfactorily. Croatia and Slovenia exhibit a rise in both Benevolence and Universalism over time, and score the highest on the Self-transcendence dimension, all of which have been shown to be good predictors of pro-environmental attitudes, including the care for nature, in our study. Hungary shows a decline in Benevolence over time, while Universalism remains at the bottom, which again supports the predictive nature of these values and adds to the explanation of its declining trend in the support for the care for nature. Finally, our research turned out a surprising result, with some basic values within Conservatism and Openness to change being positive predictors for pro-environmentalism in these countries, contrary to existing studies on other countries.

There are two main contributions of this research, regarding the relationship between Schwartz's values and pro-environmentalism, and the implications for CE countries. Firstly, in this study, pro-environmentalism was related to some expected (Self-transcendence) but also some unexpected (Conservatism) higher-order values from Schwartz's HVS when compared to the findings from other countries. As Self-transcendence and Conservatism both relate to the social/collectivist dimension (Kapoor et al., 1995; Rudnev et al., 2018), these results imply that collectivist value types, which infer the care that transcends the self, and includes others in the collective, may also extend to the entire "co-world". The findings for the basic value of Self-direction were inconclusive in other studies. Here, Self-direction, relating to creativity and freedom, although belonging to the more individualistic dimension of Openness to change, may also include this communal aspect by indicating the willingness to extend the same freedom to the "co-world" and support its diversity. Therefore, pro-environmentalism in these six CE countries seems to be related to the values that promote the sense of communalism, which can have important implications for pro-environmental policy-making in this region. Secondly, it is visible from the findings that the same countries that diverge from the overall CE trend regarding the care for nature also diverge regarding the same predictive values for the care for nature. Thus, while Croatia and Slovenia exhibit the highest care for nature and also score the highest on the value of Self-transcendence, Hungary exhibits low and decreasing Self-transcendence values over time, as well as a decreasing trend in the attitudes about the care for nature. Schwartz's HVS can, 
therefore, be predictive of pro-environmentalism in CE countries, which offers a new, previously unexplored dimension for the interpretation of their environmental attitudes and behaviour.

\section{FUNDING}

This paper was written as part of the scientific project "Social-Ecological Challenges of Rural Development” (UIP-2019-04-5257), 2020-2024, funded by the Croatian National Science Foundation.

\section{CONFLICT OF INTEREST}

Authors declare no conflict of interest.

\section{ETHICAL APPROVAL}

Not applicable [secondary data analysis].

\section{DATA ACCESS AND TRANSPARENCY}

Data available from the European Social Survey data archive:

ESS (2008). European Social Survey Round 4. NSD - Norwegian Centre for Research Data, Norway - Data Archive and distributor of ESS data for ESS ERIC. Data File Edition 4.5. https://doi.org/10.21338/NSD-ESS4-2008

ESS (2018). European Social Survey Round 9 Data. NSD - Norwegian Centre for Research Data, Norway - Data Archive and distributor of ESS data for ESS ERIC. Data File Edition 3.1. https://doi.org/10.21338/NSD-ESS9-2018_ Analytic procedures in SPSS available on request from the authors.

\section{REFERENCES}

Abramson PR and Inglehart R (1995). Value Change in Global Perspective. Ann Arbor: University of Michigan Press. https://doi.org/10.3998/mpub.23627

Brajdić Vuković M (2014). The Sustainability Potential of the Knowledge Society: Empirical Study. In: Domazet M and Marinović Jerolimov D (eds). Sustainability Perspectives From the European Semi-Periphery. Zagreb: Institut za društvena istraživanja u Zagrebu and Heinrich Böll Stiftung, 195-222. 
Brechin SR and Kempton W (1994). Global Environmentalism: A Challenge to the Postmaterialist Thesis?, Social Science Quarterly, 75( 2): 245-269.

Chaisty P and Whitefield S (2015). Attitudes Towards the Environment: Are Post-Communist Societies (Still) Different?, Environmental Politics, 24 (4): 598-616. https://doi.org/10.10 80/09644016.2015.1023575

Diekmann A and Schmidt P (1998). Special Section: Testing Rational Choice Models of Behavior Involving Environmental Issues, Rationality and Society, 10 (1): 77-78. https:// doi.org/10.1177/104346398010001003

Domazet M and Ančić B (2018). Affluence and Democratic Degrowth. In: Telešiène, A and Gross M (eds). Green European. Environmental Behaviour and Attitudes in Europe in a Historical and Cross-Cultural Comparative Perspective. London and New York: Routledge, 157-181.

Dunlap RE and Van Liere KD (1978). The "New Environmental Paradigm", Journal of Environmental Education, 9 (4): 10-19. https://doi.org/10.1080/00958964.1978.10801 875

Dunlap RE, Van Liere KD, Mertig AG and Jones RE (2000). New Trends in Measuring Environmental Attitudes: Measuring Endorsement of the New Ecological Paradigm: A Revised NEP Scale, Journal of Social Issues, 56 (3): 425-442. https://doi. org/10.1111/0022-4537.00176

Dunlap RE (2018). Foreword. A Brief History of Sociological Research on Environmental Concern. In: Telešiène, A and Gross M (eds). Green European. Environmental Behaviour and Attitudes in Europe in a Historical and Cross-Cultural Comparative Perspective. London and New York: Routledge, xvix-xxvi.

ESS Methodology Overview. https://www.europeansocialsurvey.org/methodology/ (19 February 2021)

ESS (2008). European Social Survey Round 4. NSD - Norwegian Centre for Research Data, Norway - Data Archive and distributor of ESS data for ESS ERIC. Data File Edition 4.5. https://doi.org/10.21338/NSD-ESS4-2008

ESS (2018). European Social Survey Round 9 Data. NSD - Norwegian Centre for Research Data, Norway - Data Archive and distributor of ESS data for ESS ERIC. Data File Edition 3.1. https://doi.org/10.21338/NSD-ESS9-2018

Franzen A and Meyer R (2010). Environmental Attitudes in Cross-National Perspective: A Multilevel Analysis of the ISSP 1993 and 2000, European Sociological Review, 26 (2): 219-234. https://doi.org/10.1093/esr/jcp018

Franzen A and Vogl D (2013). Two Decades of Measuring Environmental Attitudes: A Comparative Analysis of 33 Countries, Global Environmental Change, 23 (5): $1001-$ 1008. https://doi.org/10.1016/j.gloenvcha.2013.03.009

Frick J, Kaiser FG and Wilson M (2004). Environmental Knowledge and Conservation Behavior: Exploring Prevalence and Structure in a Representative Sample, Personality and Individual Differences, 37 (8): 1597-1613. https://doi.org/10.1016/j.paid.2004.02.015

Guerra J, Schmidt L and Valente S (2018). In: Telešiène, A and Gross M (eds). Green European. Environmental Behaviour and Attitudes in Europe in a Historical and CrossCultural Comparative Perspective. London and New York: Routledge, 221-242.

Hadler M and Wohlkönig P (2012). Environmental Behaviours in the Czech Republic, Austria and Germany Between 1993 and 2010: Macro-Level Trends and Individual-Level Determinants Compared, Czech Sociological Review, 48 (3): 467-492. https://doi.org/1 0.13060/00380288.2012.48.3.04 
Inglehart R (1981). Post-Materialism in an Environment of Insecurity, The American Political Science Review, 75 (4): 880-900. https://doi.org/10.2307/1962290

Inglehart R (1990). Culture Shift in Advanced Industrial Society. Princeton, NJ: Princeton University Press. https://doi.org/10.1515/9780691186740

Kaiser FG, Ranney M, Hartig T and Bowler PA (1999). Ecological Behavior, Environmental Attitude, and Feelings of Responsibility for the Environment, European Psychologist, 4 (2): 59-74. https://doi.org/10.1027/1016-9040.4.2.59

Kals E, Schumacher D and Montada L (1999). Emotional Affinity Toward Nature as a Motivational Basis to Protect Nature, Environment and Behavior, 31 (2): 178-202. https://doi.org/10.1177/00139169921972056

Kapoor S, Wolfe A and Blue J (1995). Universal Values Structure and IndividualismCollectivism: A U.S. Test, Communication Research Reports, 12 (1): 112-123. https:// doi.org/10.1080/08824099509362046

Klineberg SL, McKeever M and Rothenbach B (1998). Demographic Predictors of Environmental Concern: It Does Make a Difference How It's Measured, Social Science Quarterly, 79 (4): 734-753.

Knight KW and Messer BL (2012). Environmental Concern in Cross-National Perspective: The Effects of Affluence, Environmental Degradation, and World Society, Social Science Quarterly, 93 (2): 521-537. https://doi.org/10.1111/j.1540-6237.2012.00846.x

Kufrin K (2014). Structure and Action Potential of Environmental Attitudes and Knowledge of Environmental Problems in Croatia. In: Domazet M and Marinović Jerolimov D (eds). Sustainability Perspectives From the European Semi-Periphery. Zagreb: Institut za društvena istraživanja u Zagrebu and Heinrich Böll Stiftung, 243-276.

Lewis GB, Palm L and Feng B (2018). Cross-National Variation in Determinants of Climate Change Concern, Environmental Politics. Advanced online publication, 8 February. https://doi.org/10.1080/09644016.2018.1512261

Maloney MP and Ward MP (1973). Ecology: Let's Hear From the People: An Objective Scale for the Measurement of Ecological Attitudes and Knowledge, American Psychologist, 28 (7): 583-586. https://doi.org/10.1037/h0034936

Mayer FS and Frantz CM (2004). The Connectedness to Nature Scale: A Measure of Individuals' Feeling in Community with Nature, Journal of Environmental Psychology, 24 (4): 503-515. https://doi.org/10.1016/j.jenvp.2004.10.001

Mayerl J (2018). Environmental Concern in Cross-National Comparison: Methodological Threats and Measurement Equivalence. In: Telešiène, A and Gross M (eds). Green European. Environmental Behaviour and Attitudes in Europe in a Historical and CrossCultural Comparative Perspective. London and New York: Routledge, 182-204.

Mikecz D (2017). Environmentalism and Civil Activism in Hungary. In: Moskalewicz M and Przybylski W (eds). Understanding Central Europe. London: Routledge, 359-365. https://doi.org/10.4324/9781315157733-42

Müller M, Kals E and Pansa R (2009). Adolescents' Emotional Affinity Toward Nature: A Cross-Societal Study, Journal of Developmental Processes, 4 (1): 59-69.

Nikodem $\mathrm{K}$ and Trako Poljak $\mathrm{T}$ (forthcoming). Authoritarianism and Attitudes Toward the Environment in Croatia. A Central European Perspective. In: Values Behind the Illiberal Turn in Central Europe. Brill.

Oreg S and Katz-Gerro T (2006). Predicting Proenvironmental Behavior Cross-Nationally: Values, the Theory of Planned Behavior, and Value-Belief-Norm Theory, Environment and Behavior, 38 (4): 462-483. https://doi.org/10.1177/0013916505286012 
Rudnev M, Magun V and Schwartz S (2018). Relations Among Higher Order Values Around the World, Journal of Cross-Cultural Psychology, 49 (8): 1165-1182. https://doi. org/10.1177/0022022118782644

Schultz PW (2001). The Structure of Environmental Concern: Concern for Self, Other People, And the Biosphere, Journal of Environmental Psychology, 21 (4): 327-339. https://doi.org/10.1006/jevp.2001.0227

Schultz PW, Shriver C, Tabanico JJ and Khazian AM (2004). Implicit Connections with Nature, Journal of Environmental Psychology, 24 (1): 31-42. https://doi.org/10.1016/ S0272-4944(03)00022-7

Schultz PW and Zelezny LC (1999). Values Are Predictors of Environmental Attitudes: Evidence for Consistency Across 14 Countries, Journal of Environmental Psychology, 19 (3): 255-265. https://doi.org/10.1006/jevp.1999.0129

Schultz PW and Zelezny LC (2003). Reframing Environmental Messages to Be Congruent with American Values, Human Ecology Review, 10 (2): 126-136.

Schwartz SH (1992). Universals in the Content and Structure of Values: Theory and Empirical Tests in 20 Countries. In: Zanna M (ed). Advances in Experimental Social Psychology. Volume 25. New York: Academic Press, 1-65. https://doi.org/10.1016/ S0065-2601(08)60281-6

Schwartz SH (1994). Beyond Individualism/Collectivism: New Cultural Dimensions of Values. In: Kim U and Triandis $\mathrm{H}$ (eds). Individualism and Collectivism: Theory, Method, and Applications. London: Sage, 85-119.

Schwartz SH (2003). A Proposal for Measuring Value Orientations Across Nations, ESS Core Questionnaire Development - Human Values Proposal, 259-290. https://www. europeansocialsurvey.org/docs/methodology/core_ess_questionnaire/ESS_core_ questionnaire_human_values.pdf (19 February 2021)

Smith TW, Kim J and Son J (2017). Public Attitudes Toward Climate Change and Other Environmental Issues Across Countries, International Journal of Sociology, 47 (1): 62 80. https://doi.org/10.1080/00207659.2017.1264837

Stern PC (1999). Information, Incentives, and Proenvironmental Consumer Behavior, Journal of Consumer Policy, 22: 461-478. https://doi.org/10.1023/A:1006211709570

Stern PC (2000). New Environmental Theories: Toward a Coherent Theory of Environmentally Significant Behavior, Journal of Social Issues, 56 (3): 407-424. https:// doi.org/10.1111/0022-4537.00175

Trako Poljak T, Cifrić I, Bukvić-Letica A and Tomić T (2018). Prava živog svijeta i etičnost čovjekova djelovanja prema prirodnom svijetu, Sociologija i prostor, 56 (3): 193-226. https://doi.org/10.5673/sip.56.3.1

Weigel R and Weigel J (1978). Environmental Concern: The Development of a Measure, Environment and Behavior, 10 (1): 3-15. https://doi.org/10.1177/0013916578101001

Wiseman M and Bogner F (2003). A Higher-Order Model of Ecological Values and its Relationship to Personality, Personality and Individual Differences, 34 (5): 783-794. https://doi.org/10.1016/S0191-8869(02)00071-5 


\title{
Odnos između Schwartzovih vrijednosti i brige o prirodi u Hrvatskoj i pet srednjoeuropskih zemalja na temelju podataka iz 4. (2008.) i 9. runde (2018.) Europskoga društvenog istraživanja
}

\author{
Bruno ŠIMAC (D) https://orcid.org/0000-0003-1361-9622 \\ Odsjek za sociologiju, Filozofski fakultet Sveučilišta u Zagrebu, Hrvatska \\ bsimac@ffzg.hr \\ Tijana TRAKO POLJAK (D) htps://orcid.org/0000-0002-0846-2889 \\ Odsjek za sociologiju, Filozofski fakultet Sveučilišta u Zagrebu, Hrvatska \\ ttrako@ffzg.hr \\ Vladimir IVANOVIĆ (D) https://orcid.org/0000-0001-8789-3486 \\ Odsjek za sociologiju, Filozofski fakultet Sveučilišta u Zagrebu, Hrvatska \\ vivanovi@ffzg.hr
}

\section{SAŽETAK}

Ovaj rad istražuje brigu o prirodi u Hrvatskoj na temelju podataka 4. (2008.) i 9. runde (2018.) Europskoga društvenog istraživanja (EDI, engl. European Social Survey - ESS), tijekom vremena i u usporedbi s pet drugih zemalja srednje Europe (Češka, Mađarska, Poljska, Slovačka i Slovenija). Čestica o brizi za prirodu korelirana je s vrijednostima mjerenima na Schwartzovoj ljestvici (engl. Human Values Scale - HVS) iz EDI-ja, kako bismo provjerili jesu li vrijednosti, kako in je definirao Schwartz, dobri prediktori brige o prirodi u ovih 6 zemalja srednje Europe. Provjerili smo i povezanost s ključnim sociodemografskim obilježjima ispitanika (dob, spol, obrazovanje, politička orijentacija i religioznost). Analiza je pokazala da, iako postoje sličnosti u pogledu ekoloških stavova i vrijednosti među odabranim zemljama srednje Europe, postoje i neke pojedinačne razlike među njima. U Hrvatskoj pronalazimo najsnažniji porast potpore za brigu o prirodi tijekom obuhvaćenog razdoblja od 10 godina, a Hrvatska i Slovenija imaju najviši rezultat vezano za brigu o prirodi u 2018. godini. Poljska, Slovačka i Češka bilježe ukupnu stagnaciju u rezultatima, a Mađarska pokazuje značajno smanjenje potpore za brigu o prirodi između 2008. i 2018. godine. Naše istraživanje otkriva da su Schwartzove vrijednosti, osobito one "nadilaženja sebe" (engl. Self-transcendence) i, suprotno postojećoj literaturi, "konzervatizma" (engl. Conservatism), umjereno dobri prediktori brige o prirodi. Te vrijednosti naglašavaju važnost društva (a samim time i cijeloga "susvijeta") nad individualnim interesima, što pruža novu dimenziju za tumačenje stavova o okolišu u ovim zemljama.

Ključne riječi: Schwartzova ljestvica vrijednosti, pro-ekološki stavovi, Europsko društveno istraživanje, srednja Europa, Hrvatska 
